\title{
Poverty and the social participation of young people-an analysis of poverty-related withdrawal mechanisms
}

\author{
Andreas Damelang • Georgi Kloß
}

Published online: 15 October 2013

(C) Institut für Arbeitsmarkt- und Berufsforschung 2013

\begin{abstract}
This paper analyses poverty-specific withdrawal mechanisms of children and adolescents. A lower social participation rate in extracurricular organisations decreases opportunities for informal learning and consequently reduces life chances. Poverty research has demonstrated that financial constraints and the social withdrawal that result from feelings of shame cause lower participation rates. By dividing extracurricular leisure activities into fee-based and noncontributory activities, it is possible to discriminate between the two mechanisms. Our empirical crosssectional analysis is based on the panel study "Labour Market and Social Security" (PASS). The results demonstrate that primarily financial shortages explain decreased participation opportunities and to a substantially lesser extent social withdrawal. Additionally, the findings suggest that social deprivation occurs only in situations of long-lasting poverty.
\end{abstract}

\section{Armut und soziale Teilhabe von Kindern und Jugendlichen - Eine Analyse armutsspezifischer Rückzugsmechanismen}

Zusammenfassung Ziel des Aufsatzes ist es, armutsspezifische Rückzugsmechanismen von Kindern und Jugendlichen $\mathrm{zu}$ analysieren. Eine geringere soziale Teilhabe in außerschulischen Organisationen reduziert die Möglichkeiten informellen Lernens und mindert infolgedessen Le-

\footnotetext{
Dr. A. Damelang $(\varangle) \cdot$ G. Kloß

Chair of Sociology and Empirical Social Research, School of

Business and Economics, Friedrich-Alexander-University

Erlangen-Nuremberg, Findelgasse 7/9, 90402 Nuremberg,

Germany

e-mail: andreas.damelang@wiso.uni-erlangen.de

G. Kloß

e-mail: georgikloss@gmail.com
}

benschancen. Aus der Armutsforschung ist bekannt, dass finanzielle Restriktionen und ein sozialer Rückzug aufgrund von Schamgefühlen in geringeren Teilhabequoten münden. Indem wir kostenpflichtige von beitragsfreien Freizeitangeboten unterscheiden, kann zwischen beiden Mechanismen diskriminiert werden. Die empirische Querschnittsstudie auf Basis des Panels für Arbeitsmarkt und Soziale Sicherung (PASS) gibt eindeutige Hinweise darauf, dass vor allem ökonomische Knappheit und in viel geringerem Maße ein sozialer Rückzug verringerte Teilhabechancen erklären. Die Befunde deuten zudem darauf hin, dass soziale Deprivation sich erst bei verstetigter Armut niederschlägt.

\section{Introduction}

In the public discourse on equal access to education and participation opportunities, informal learning usually plays a minor role. However, the acquisition of extracurricular skills during childhood and adolescence is increasingly important (Stecher 2005) to secure the individual benefits required to compete for coveted jobs and traineeship positions (Zinnecker 1994). Informal learning does not occur in pedagogically approved contexts but in everyday life (Lipski 2000). Participation in organised sports, music and cultural activities with peers plays a major role.

Social origin influences formal and informal learning opportunities. In particular, children and young individuals who are at risk of poverty or affected by poverty have diminished opportunities. Recent studies have demonstrated that the social background of young individuals strongly determines their social participation (Düx et al. 2008; Engels and Thielebein 2010; Gaiser and Rijke 2006; Gensicke et al. 2006; Otto and Kutscher 2004). Especially young people with lower socio-economic status have a lower participation rate in, for example, sport clubs or organisations. 
In particular, socially better-off and integrated youth benefit from the positive effects of participation. The welfare state ensures the provision of the material basic needs (e.g., housing, food, and clothing) of needy children. However, the satisfaction of cultural and social needs is deficient. To counteract these deficiencies, the federal government introduced the so-called "educational package" ("Bildungs- und Teilhabepaket") in 2011, which aimed "to improve the social integration of children and young people into existing clubs and community structures and to intensify the contact with their peers" (Sauer and Kossens 2011, p. 870; translated by the authors). Therefore, the government pays club and course fees up to $€ 10$ monthly for young individuals who receive Unemployment Benefit II $\left(\mathrm{ALG} \mathrm{II}^{1}\right){ }^{2}$ The "educational package" is based on the assumption that children and young people from poor and needy families are excluded from such services because of the costs of social participation.

Poverty research has demonstrated that monetary resources restrict opportunities for participation but that withdrawal also occurs because of shame. Poor children and youth are ashamed of the poverty of their parents and internalise their parents' lack of self-esteem (Gillen and Möller 1992). Thus, they withdraw from previous contacts or avoid them from the beginning (Kern 2004). Both mechanisms-financial constraints and social withdrawal because of shame-result in an accumulation of educational disadvantages for children and young individuals affected by poverty, although the socio-political approach only focuses on the first mechanism.

This article addresses the question of whether financial constraints restrict participation in extracurricular contexts or whether withdrawal is causative. To investigate this question empirically, we divide extracurricular leisure activities into fee-based and non-contributory organisations. If financial constraints are the decisive factor for participation, different participation rates should be found only in fee-based and not in non-contributory organisations. However, if financial constraints only play a minor role with social withdrawal being the main cause, then lower participation should also be observed in non-contributory organisations. We operationalise participation in sport, music or cultural clubs as fee-based activities and leisure activities organised by church communities as non-contributory activities. The access to both types of leisure opportunity is open to all regardless of social or religious background.

\footnotetext{
${ }^{1}$ ALG II: Arbeitslosengeld II (in English: Unemployment Benefit II).

${ }^{2}$ In addition, recipients of social assistance, the children's allowance and the housing allowance are entitled to benefits. Overall, approximately 2.5 million children and adolescents in Germany qualify for the "educational package" (BMAS 2012).
}

To disentangle poverty-related withdrawal mechanisms, we use the panel study "Labour Market and Social Security" (PASS), which was developed for the labour market, welfare state and poverty research in Germany (Trappmann et al. 2010). The survey data are well suited for the study of needy individuals and their participation in society because of the oversampling of recipients of benefits in accordance with the German Social Code Book II. In the following sections, we first explain the importance of informal learning and then discuss the mechanisms of social withdrawal with regard to participation in extracurricular leisure activities. Then, we present the data, our research design and the empirical findings. Finally, we summarise the results and discuss socio-political implications.

\section{Theoretical background}

\subsection{Education is more than school}

In the institutionally organised educational system, young people acquire knowledge and skills, which later can be profitably used in the labour market (Becker 1962). In addition to formal and certified human capital, extracurricular acquired knowledge and skills affect future opportunities. According to Dohmen (2001), 70 per cent of all human learning processes occur outside educational institutions. ${ }^{3}$ Following Bourdieu (1983), we refer to the set of skills and abilities as cultural capital.

It is undeniable that cultural capital is also acquired outside formal educational institutions. However, it is difficult to answer the question of which skills are imparted and under what conditions they are acquired. Generally, the acquisition of cultural capital and the social processes of identity formation and social positioning depend on familial, leisure, cultural and friendship-related socialisation environments (Thole and Höblich 2008; Tully and Wahler 2004). In the course of cognitive socialisation, individuals acquire specific knowledge and skills, within which different forms and phases can be distinguished. Parents pass cultural capital to their children during the early socialisation phases. This transmission and internalisation of cultural capital primarily occurs without a specific intention but rather unconsciously during a child's socialisation (Bourdieu 1983). Later in life, new social contexts are encountered and the acquisition of knowledge and skills outside the parental home gains in importance. In a broader sense of education, we can differentiate between formal, non-formal and informal learning. Non-formal learning processes occur outside educational institutions and although participation is voluntary,

\footnotetext{
${ }^{3}$ This number should be understood as a heuristic rather than an empirically verified fact.
} 
these processes occur in pre-structured educational settings similar to schools (Stecher 2005). Learning is referred to as "informal" if it does not occur in pedagogically supervised situations and is directly based on real-life situations (Lipski 2000).

In addition to the family, peer groups offer important opportunities for informal learning (Düx and Rauschenbach 2010). The capital acquired in peer groups plays an important role with respect to the further social and occupational opportunities of young people (Rauschenbach et al. 2004). Clubs, organisations, churches and public institutions are important locations in which peers can gather. Active young individuals acquire knowledge and skills that enable them to act meaningfully and successfully in their organisations and thereby become socially integrated into the community. Moreover, such individuals can use their club-related cultural capital outside their clubs, for example, in school, training or work. Additionally, the skills obtained in such sociocultural distinctions and identification fields (Isengard 2005) are useful in the labour market and facilitate addressing new or problematic circumstances (Grunert 2006).

A survey of club members conducted by Braun et al. (2007b) provides insight into the various forms of attained cultural capital. The results demonstrate that respondents primarily develop general and specialised knowledge, social skills and intervention abilities. In addition, many extracurricular organisations offer favourable opportunities to establish social relationships and entire social networks because of their small size (Braun et al. 2007a). This social capital is based on group membership and ensures that young people are socially integrated into their organisations. Furthermore, these individuals have access to those resources outside the organisations and benefit from individual assistance, emotional support and social approval.

If young people obtain access to extracurricular organisations, they can increase their cultural and social competencies, particularly through informal learning processes. The factors that determine the opportunities to enter these extracurricular organisations are thus of particular importance. Therefore, a possible link between poverty and informal learning opportunities would result in a decrease in life chances. Unequal participation in extracurricular organisations may result in an uneven distribution of social and cultural capital.

\subsection{Poverty-induced barriers to extracurricular organisations}

It is an empirical fact that poverty minimises social participation opportunities and can result in social isolation in the long run (for an overview see, for example, Andreß et al. 1995). For example, Brinkmann (1984) demonstrates that the unemployed do not spend the extra time afforded by their unemployment on leisure activities. On the contrary, they abandon leisure activities more often than employed persons (Diewald 2007). According to Kern (2004), a scarcity of resources and the individual withdrawal of the affected can result in social isolation. ${ }^{4}$ The scarcity of resources is the direct effect of poverty, which means that the affected simply do not possess enough money to participate in extracurricular leisure activities. However, individual withdrawal in response to a deprived life situation is an indirect effect of poverty. From a social policy perspective, both mechanisms are problematic, although the possible responses differ.

If young individuals are poor or at risk of poverty, they will possess fewer financial resources. Needy individuals cannot participate in a large number of social activities if the activities are fee-based. Disadvantages in informal learning in extracurricular contexts occur simply because the access conditions cannot be fulfilled. The expense of the leisure activities of children can significantly increase the financial burden of families. Leisure expenses for children increase after age 13, depending on the children's activities (Bauer 1998). Sport clubs are by far the most popular institutionalised recreational activities in Germany (Engels and Thielebein 2010). According to the Sport Development Report $2007 / 2008$, the average monthly membership fee is $€ 11.59$ for young individuals and $€ 22.32$ for adults (Breuer 2009). This average fee does not include additional expenses for equipment and training hours. The cost of music lessons as well as public and municipal music schools are often even higher. Given the many different costs involved in the study of music (e.g., individual and group lessons and the purchase of musical instruments) specific figures cannot be presented. Art and acting classes as well as attendance at cultural events are also associated with high costs. In addition, courses with artistic content are only feasible for small groups, which tends to result in higher fees.

Thus, the non-participation in extracurricular organisations is directly linked to economic deficits. Economic constraints cause social withdrawal. However, the indirect costs of maintaining social contacts are also significant. Perceived social support from social contacts relies in most cases on the principle of reciprocity. Thus, individuals who assess their credibility as low will refuse any support that requires compensation, and they will finally withdraw from those relationships (Andreß et al. 1995). In addition, behavioural adaptations of the poor to their circumstances may also result in withdrawal because these individuals feel ashamed of their social position (Gillen and Möller 1992). Writers as early as Adam Smith (1790) noted that poverty is not only characterised by a material deficit. In particular, feelings of shame, self-doubt and social isolation also

\footnotetext{
${ }^{4} \mathrm{~A}$ third mechanism is processes of exclusion caused by the stigmatisation of the poor. In Germany, the effect of stigmatisation is considered to be low, particularly compared with the U.S. (Leibfried et al. 1995).
} 
influence the behaviour and self-perception of the needy. Self-esteem is significantly determined by positive affirmations of identity within reference groups (Cast and Burke 2002). If these positive affirmations are not available, a lack of self-consciousness and shame can be the result. Needy young individuals most likely feel or experience uselessness more often and consequently build up only a lower level of self-esteem. These effects are strengthened when low selfesteem is also mediated by the parents. However, a welldeveloped sense of self-esteem, is an important prerequisite to the establishment of social relationships (Puls 1989). If young individuals avoid social contacts because they are afraid to attract attention as a result of their poor economic situation, a withdrawal from extracurricular organisations will follow.

\subsection{Summary of considerations and implications}

Poverty can result in fewer social participation opportunities and is associated with reduced opportunities for informal learning. The underlying mechanisms differ and thus, possible problem-solving strategies vary. The financial barriers argument seems obvious and possesses the advantage that it can be solved with "simple" socio-political measures, such as the "educational package" introduced by the federal government for needy youth. However, social withdrawal that results from behavioural adaptations is substantially more difficult to address.

To empirically test whether the direct or indirect effects of poverty are significant, we examine the probability that needy and non-poor young individuals will participate in extracurricular organisations but separate this participation into fee-based and non-contributory activities. If both mechanisms apply, we would expect less participation by poor young individuals in fee-based and non-contributory organisations. However, if the financial factor postulated by the federal government is causative, we would expect less participation in fee-based but not in non-contributory activities.

\section{Empirical approach}

\subsection{Database}

If one focuses upon needy young individuals, one must choose data with a sufficient number of observations for this group. In Germany, 8.8 per cent of young people between 15 and 24 years of age receive Unemployment Benefit II (ALG II), which is slightly higher than the German average (Bundesagentur für Arbeit 2012). Subsequently, in most population studies, representative data on impoverished households are seldom available. The panel study "Labour Market and Social Security" (PASS) is an annual household survey, which is designed for labour market, welfare state and poverty research in Germany (Trappmann et al. 2010). PASS consists of two partial populations: persons and households that receive Unemployment Benefit II and persons and households registered as residents of Germany. Representative statements for the entire population can be made using a weighting procedure. Thus, PASS is the only dataset available in Germany that provides a sufficient number of observations to analyse the influence of poverty on extracurricular participation opportunities.

\subsection{Operationalisation of extracurricular organisations}

We operationalise participation in extracurricular organisations with the question of to what extent one is active in organisations. Herein, we construct three variables: (1) active in at least one organisation, (2) active in a music, sport or culture club and (3) active in a church community. The dependent variable "active in a church community" represents non-contributory activities, whereas the dependent variable "active in a music, sport or culture club" represents fee-based activities. The dependent variable "active in at least one organisation" serves to examine the plausibility of the results and consists of both dependent variables. The wording of the question enables us not to discriminate between membership and activity. ${ }^{5}$ Membership constitutes an important form of social participation. However, it is not compulsively connected with active participation in clubs events and the accompanying accumulation of cultural capital. Thus, we cannot affirm that the available answer alternatives (active/not active) have been unambiguously interpreted by the respondents and that those members who are not active answered "not active". Furthermore, the question's wording includes individuals who are active in one way or another without being members.

Prior to offering any statements regarding the different participation rates of poor and non-poor young individuals in fee-based and non-contributory organisations, we should discuss the possible selection effects of these organisations. The most straightforward approach would be to divide music, sport or culture clubs into fee-based and non-contributory activities and analyse the different participation rates based on this differentiation. However, the PASS information does not facilitate this differentiation and we cannot use other data because of the small number of needy young individuals. Therefore, we employ activities in church communities as a proxy for non-contributory organisations. In addition to youth services and confirmation preparation, the open youth work of churches provides examples of non-binding offers that occur in the course of

\footnotetext{
${ }^{5}$ The wording of the question was as follows: "Are you active in one of the following associations or clubs?"
} 
leisure activities, educational work and independent youthcultural development (Höß 2004). In the open youth work of churches, shared activities and social relationships with peers occupy the foreground, whereas the reference to the church as institution is of minor importance (EKD 2010). To control for possible entry barriers, we additionally take into account the individual religious persuasion in the multivariate analysis. Furthermore, church communities are a major organiser of youth leisure activities. Approximately 660,000 young individuals aged between 7 and 28 years are organised in the Catholic Church (Deutsche Bischofskonferenz 2012) and the Protestant youth organisation represents the interests of approximately 1.2 million young people (AEJ 2010). A 2007 study in cooperation with the Free University of Berlin reveals that 10 per cent of all German youths participate or have participated in activities offered by the Protestant youth organisation (EKD 2010). The different leisure activities vary from youth clubs and disco evenings to cultural offerings and adventure-based learning activities and are mostly free of charge. Moreover, a membership in one of the church-related groups costs between $€ 15$ and $€ 25$ (DPSG 2011; KJG 2011) and allows participation in workshops and day trips. Thus, leisure activities organised by the church are substantially more affordable than those of most clubs and other organised groups.

Of course, there are additional non-contributory, institutionalised leisure activities, for example, public or private financed leisure facilities for youth. Although the given operationalisation represents the numerically most important organisations, it does not cover all non-contributory activities and opportunities for informal learning. Thus, if the analysis reveals a lower participation rate for the poor, we might overestimate this rate. The operationalisation of noncontributory organisations using leisure activities organised by church communities is not fully satisfying. However, given the available data, this approach represents the most promising solution and provides insight into poverty-related withdrawal mechanisms.

\subsection{Data preparation and design}

The population under investigation refers to the third wave of PASS which was conducted in 2008 and 2009 (that is, 2 years before the educational package was implemented). We select all of the respondents who are between 15 and 24 years of age. To represent the economic situation of the young individuals and particularly whether they are affected by poverty, we distinguish three groups: (1) no poverty, (2) relative but not combated poverty and (3) combated poverty. The category "combated poverty" includes all persons and households who receive social welfare benefits (Hauser 1996). This group includes households that receive basic social benefits for employable beneficiaries in accordance with the German Social Code Book II (e.g., ALG II).
The previously mentioned "educational package" is part of these benefits. The relative but not combated poverty group complements the combated poverty group. The difference is that these households do not receive Unemployment Benefit II. Based on a joint consideration of the EU member states, the poverty line is established at 60 per cent of the median national equivalent income (Deckl 2011). The net household equivalence income takes different household sizes into account. Based on the employed PASS data, we obtain a median equivalent income of $€ 1,333$ and a poverty line of $€ 800$. Thus, the relative but not combated poverty group consists of those young individuals whose household income is below that level but who do not receive Unemployment Benefit II. If individuals are affected by either combated or relative poverty, we assign them to the remaining group.

Because the assignment to the groups refers to the household of each respondent, we ascertain whether the adolescent is living with his or her parents. In addition, we consider employment status, whereby pupils, apprentices and students are included in the group "in education". The educational level is a combination of the aspired-for or the highest achieved educational degree, depending on whether the respondent still attends school. Therefore, for example, we avoid assigning 15-year-old pupils to the group of respondents without educational degrees. We assign a migration background if the respondent or at least one parent has immigrated. The age is centred on the average age of the group under investigation (19 years). Although activities in church communities are not necessarily associated with religious affiliation, we include this variable in the analysis to avoid bias. Because the third wave of PASS does not provide this information, we used the religious affiliation data from previous waves. Those persons who were not interviewed during the previous waves are assigned to the group "religious affiliation unknown". We can differentiate between the following four groups: no religious affiliation, Christian, Non-Christian and religious affiliation unknown. Finally, we operationalise the highest parental educational degree as indicator for social background. We aggregate the information available in the record into a variable with four values: upper secondary education, secondary education, lower secondary education and without educational degree. Table 1 displays the composition of the investigated population and the marginal distribution of the variables used. The numbers of observations displayed in Table 1 are not weighted, whereas the marginal distributions are.

Overall, we have 1.939 valid observations. Examining the dependent variables, we observed that 49 per cent are active in at least one organisation, whereas 15 per cent are active in a church community and 43 per cent in a music, sport or culture club. The higher total sum is the result of certain young individuals being active in more than 
Table 1 Composition of the investigated population

$\begin{array}{llll}n^{+} & \text {Mean } & \text { SD } & \min / \max \end{array}$

1. Dependent variables

Active in at least one organisation

Active in music, sport or culture club

Active in religious community

2. Independent variables

Poverty

Not poor

Poor $^{++}$, no ALG II

Poor and ALG II

Employment status

In education

Employed

-1pt Unemployed

Other

(Desired) Educational degree

Upper secondary

Secondary

Lower secondary

Socio-demographics

Age (years)

Sex (female)

Migration background

Lives with parents

Religious affiliation

No religious affiliation

Christian

Non-Christian

Affiliation unknown

Highest parental educational degree

Upper secondary

Secondary

Lower secondary
No/other degree
697

610

192

818

359

762

1,231

226

370

112

589

686

664

1,939

992

370

1,344

523

699

116

601

519

669

505

246
0.73

0.18

0.09

0.68

0.18

0.09

0.06

0.44

0.29

0.27

19.48

0.48

0.14

0.69

0.22

0.45

0.07

0.26

0.39

0.32

0.19

0.09
0/1

$0 / 1$

0/1

$0 / 1$

$0 / 1$

$0 / 1$

$0 / 1$

0/1

$0 / 1$

$0 / 1$

+ Unweighted figures

${ }^{++}$Less than 60 per cent of the median national equivalent household income

Source: PASS, third wave, weighted figures

one organisation. In addition, we can observe that needy households are overrepresented in PASS. The sample consists of 762 persons living in a household that receives Unemployment Benefit II. We can present representative statements for the entire population using a weighting procedure. That is, 73 per cent belong to the not poor group, 18 per cent belong to the relatively poor but not com- bated group and 9 per cent belong to the combated poor group.

\subsection{Methodological procedure}

To estimate the influence of poverty on participation rates in organisations, we employ a binary logistic regression. We estimate three independent regression models starting 
Table 2 Social participation of the various (poverty) groups

\begin{tabular}{|c|c|c|c|c|c|c|c|c|}
\hline \multirow[t]{2}{*}{ Social participation } & \multicolumn{2}{|c|}{ Not poor } & \multicolumn{2}{|c|}{ Poor $^{++}$, no ALG II } & \multicolumn{2}{|c|}{ Poor and ALG II } & \multicolumn{2}{|c|}{ Total } \\
\hline & $\overline{n^{+}}$ & Per cent & $\overline{n^{+}}$ & Per cent & $\overline{n^{+}}$ & Per cent & $\overline{n^{+}}$ & Per cent \\
\hline Active in at least one organisation & 401 & 53 & 119 & 46 & 177 & 22 & 697 & 49 \\
\hline Active in music, sport or culture club & 361 & 48 & 95 & 33 & 154 & 20 & 610 & 43 \\
\hline Active in religious community & 116 & 16 & 37 & 19 & 39 & 3 & 192 & 15 \\
\hline
\end{tabular}

+ Unweighted figures

${ }^{++}$Less than 60 percent of the median national equivalent household income

Source: PASS, third wave, weighted figures

with the dependent variable "active in at least one organisation". Then, we examine the probability of participation in music, sport or culture clubs and compare such activities with activities in church communities to detect inhibitory effects on social participation. Because the estimated logarithmised probabilities might be biased for each group as a result of unobserved heterogeneity (Auspurg and Hinz 2011), we present the results as average marginal effects (AMEs). The advantage of this strategy is that the interpretation is more intuitive because AMEs display the average additive effect on the probability compared with the reference category (Wolf and Best 2010).

\section{Empirical findings}

Prior to the presentation and discussion of the results of the regression analysis, the descriptive presentation presents an initial insight into different participation rates. Table 2 shows the social participation of the three defined (poverty) groups. The three dependent variables are each set in relation to these groups. The percentage distribution in Table 2 corresponds to weighted figures and the displayed numbers of observations are unweighted.

The descriptive results in Table 2 reveal that activity in at least one organisation in Unemployment Benefit II households is less distinct than in the other two groups. That is, only 22 per cent of young individuals who receive Unemployment Benefit II are active in an organisation, whereas 46 per cent and 53 per cent, respectively, of young individuals who do not receive Unemployment Benefit II are active. To analyse the postulated mechanisms, leisure activities are separated into fee-based and non-contributory activities. In the relative poverty group, 33 per cent participate in fee-based music, sport or culture clubs compared with 20 per cent in the combated poverty group. In contrast, 48 per cent of the young individuals who are not affected by poverty are active. Thus, the descriptive analysis demonstrates a lower participation rate of poor young individuals in fee-based organisations. However, participation in non-contributory church activities is unevenly distributed among the different groups. Notably, the relatively poor and non-poor groups are similar, whereas the combated poverty group is active to a much lesser extent. Young individuals from a household that receives Unemployment Benefit II are significantly underrepresented with a participation rate of 3 per cent. In contrast, the rate of activity for young individuals with relative income poverty is above average (19 per cent vs. 15 per cent). In sum, the descriptive results demonstrate a clear link between poverty and lower social participation. In addition, distinguishing between relative and combated poverty is profitable because young individuals who receive Unemployment Benefit II are strongly affected, whereas the effect for the relative but not combated poverty group is only partly observable.

The second step of our analysis supports the descriptive results with a multivariate analysis. Table 3 reports the results of our three binary logistic regression models. Model 1 shows the average marginal effects for the probability of being active in at least one organisation. Models 2 and 3 distinguish the activity in fee-based and non-contributory organisations. Thus, model 2 examines the impact of financial constraints, whereas model 3 focuses on social withdrawal. If financial restrictions are primarily decisive, we expect significant effects of poverty only in model 2 . However, if in addition a general social withdrawal is causative, poverty effects should also be significant in model 3. The group of young individuals who are not affected by relative or combated poverty serves as the reference group. In addition to poverty, in each model, we control for socio-demographic characteristics, employment status, the (desired) educational degree, religious affiliation and the educational degree of the parents. These control variables prove to be stable in all of the models and are consistent with the empirical literature. The average marginal effects shown in Table 3 are obtained from logistic regressions using unweighted figures.

Model 1 in Table 3 shows a clear negative relationship between social participation in extracurricular organisations and poverty. In addition, the effect is evident for poor youth without Unemployment Benefit II, although weaker and 
Table 3 Impact of poverty on participation opportunities in organisations ${ }^{+}$

\begin{tabular}{|c|c|c|c|}
\hline & $\begin{array}{l}\text { At least one organisation } \\
\text { (Model 1) }\end{array}$ & $\begin{array}{l}\text { Music, sport or culture } \\
\text { club } \\
\text { (Model 2) }\end{array}$ & $\begin{array}{l}\text { Religious community } \\
\text { (Model 3) }\end{array}$ \\
\hline \multicolumn{4}{|l|}{ Poverty } \\
\hline Not poor & $($ Ref. $)$ & $($ Ref. $)$ & $($ Ref. $)$ \\
\hline Poor $^{++}$, no ALG II & $-0.0564^{*}$ & $-0.0832^{* *}$ & 0.0036 \\
\hline Poor and ALG II & $-0.1277^{* * *}$ & $-0.1317^{* * *}$ & $-0.0374 *$ \\
\hline \multicolumn{4}{|l|}{ Employment status } \\
\hline In education & 0.0597 & 0.0590 & 0.0243 \\
\hline Employed & 0.0619 & 0.0484 & 0.0472 \\
\hline Unemployed & $($ Ref. $)$ & (Ref.) & (Ref.) \\
\hline Other & 0.0162 & 0.0359 & 0.0130 \\
\hline \multicolumn{4}{|c|}{ (Desired) Educational degree } \\
\hline Upper secondary & $0.1764^{* * *}$ & $0.1696^{* * *}$ & $0.0613^{* *}$ \\
\hline Secondary & $0.0524^{*}$ & 0.0485 & $0.0425^{*}$ \\
\hline Lower secondary & $($ Ref. $)$ & $($ Ref. $)$ & $($ Ref. $)$ \\
\hline \multicolumn{4}{|l|}{ Socio-demographics } \\
\hline Age (years) & $-0.0245^{* * *}$ & $-0.0250^{* * *}$ & -0.0041 \\
\hline Sex (female) & $-0.0758^{* * *}$ & $-0.0976^{* * *}$ & 0.0168 \\
\hline Migration background & $-0.0829^{* *}$ & $-0.0610^{*}$ & $-0.0450^{*}$ \\
\hline Lives with parents & 0.0324 & 0.0307 & -0.0177 \\
\hline \multicolumn{4}{|l|}{ Religious affiliation } \\
\hline No religious affiliation & $($ Ref. $)$ & (Ref.) & $($ Ref.) \\
\hline Christian & $0.1466^{* * *}$ & $0.0745^{* *}$ & $0.2091^{* * *}$ \\
\hline Non-Christian & 0.0917 & 0.0795 & 0.0601 \\
\hline Affiliation unknown & $0.1149^{* * *}$ & $0.0724^{*}$ & $0.1710^{* * *}$ \\
\hline \multicolumn{4}{|c|}{ Highest parental educational degree } \\
\hline Upper secondary & $0.1198^{* * *}$ & $0.1193^{* * *}$ & 0.0209 \\
\hline Secondary & 0.0703 & 0.0672 & 0.0185 \\
\hline Lower secondary & 0.0569 & $0.0824^{*}$ & -0.0175 \\
\hline No/other degree & $($ Ref. $)$ & $($ Ref. $)$ & $($ Ref. $)$ \\
\hline$N$ & 1.939 & 1.939 & 1.939 \\
\hline Log likelihood & $-1,079.7609$ & $-1,037.6284$ & -536.3722 \\
\hline McFadden's pseudo $R^{2}$ & 0.1474 & 0.1407 & 0.1434 \\
\hline
\end{tabular}

${ }^{* * *} p<0.001,{ }^{* *} p<0.01,{ }^{*} p \leq 0.05$

+ Average marginal effects obtained from logistic regression using unweighted figures

${ }^{++}$Less than 60 percent of the median national equivalent household income

Source: PASS, third wave, unweighted figures

only significant at the 95 per cent level. In general, poverty decreases opportunities for social participation. Model 2 reveals that poverty decreases in particular the participation in fee-based activities. Income poverty significantly lowers the probability of being active in a music, sport or culture club, which applies to both needy groups. Young individuals affected by relative poverty are less likely to be active in a fee- based organisation than non-poor youth (minus 8 per cent). For young individuals who receive Unemployment Benefit II, the probability of an activity decreases by a highly significant 13 per cent. By examining the participation in noncontributory church activities (model 3 ), it is possible to discriminate between the two postulated mechanisms. That is, we observe a significantly reduced poverty effect. Signifi- 
cant differences between non-poor and relatively poor youth are statistically non-existent, whereas the receipt of Unemployment Benefit II has a weak significant negative impact. For these individuals, the probability of being active in noncontributory organisations is 4 per cent lower than that of their peers who are not affected by poverty.

The results of the three regression models present a clear picture. Financial restrictions result in less social participation and subsequently decrease the opportunities for informal learning. The government's "educational package" may counteract these restrictions. In contrast, a general social withdrawal of children and adolescents as a result of feelings of shame seems not to explain lower social participation. However, it is useful to differentiate between needy youth and needy youth who receive Unemployment Benefit II. Regarding the latter, there is little evidence for this mechanism. However, this result is only slightly significant. Thus, we cannot completely rule out that feelings of shame decrease participation rates. Conceivably, the receipt of social welfare benefits (e.g. Unemployment Benefit II) constitutes poverty (Simmel 1908) and thus lowers self-esteem (Coser 1992). However, even if this mechanism is active, it is not universal and of minor importance-at least in this analysis. Thus, the derived implications can be confirmed. Social withdrawal as a result of financial restrictions is the primary mechanism.

Additionally, the regression results demonstrate a clear correlation between the level of education and social participation. Young individuals with upper secondary and with secondary education are more likely to be active in an organisation than their peers with lower secondary education. Furthermore, women are significantly less active. Perhaps the given structures still support processes of segregation (Gaiser and Rijke 2006). Moreover, young individuals with a migration background have a lower participation probability, which may be caused by cultural and social barriers. Age has a highly significant negative impact on participation. Maturation is often accompanied by status changes or changes of residence, which means that commitments established during younger days will be abandoned. ${ }^{6}$ In sum, younger men without a migration background and with high educational aspirations whose parents possess a high-school diploma and whose household is unaffected by poverty have the highest probability to participate in organisations.

A Christian religious affiliation, which was primarily integrated as a control variable related to participation in religious activities, displays a significant positive impact on participation in all of the models. Young Christians are more

\footnotetext{
${ }^{6}$ Living in a disadvantaged area may also entail limited opportunities to participate in extracurricular leisure activities. Hence, in a further step we have also controlled for East and Western Germany but without finding significant differences (results are not reported here). A further breakdown of living regions is not appropriate due to data limitations.
}

likely to be active in at least one organisation than their peers who are not religiously affiliated. A possible explanation might be that Christians practise participation in public events (services) and integration into social groups (preparation for communion and confirmation) from an early age. Thus, a general interest in social participation might be awakened, which also favours participation in music, sport or culture clubs. Another explanation is that Christianity is an indicator of the latent dimension of "social integration", which also has a positive effect on social participation in general (Traunmüller 2009).

\section{Summary and Outlook}

This paper's aim was to examine the connection between poverty and the social participation of young people. In addition to an integration effect, social participation in extracurricular organisations provides knowledge and skills, which can be profitably incorporated in other social contexts, such as school and work. However, access to organisations in which informal learning processes occur may be limited as a result of various mechanisms, particularly for needy children and young individuals. Two mechanisms have been identified that may explain a lower participation rate. First, participation is associated with significant costs, such as membership fees and equipment. Being affected by poverty means that financial resources are limited. Participation and expenses in one area exclude participation in other areas. Second, a lower participation rate may be the result of psychosocial adaptation strategies. Contact with others is avoided because of lower self-esteem and shame regarding one's circumstances.

The results have demonstrated that poverty considerably restricts participation in fee-based organisations. Financial constraints decrease the opportunities for social participation, which strongly limits informal learning opportunities. However, less participation in non-contributory activities, which reflects the processes of social withdrawal, is not clearly evident. In particular, a lesser probability of participation was not detected for needy young individuals who do not receive Unemployment Benefit II. This result suggests that social deprivation most likely occurs only when poverty is long-lasting. However, it is worth mentioning that we do not test social withdrawal and financial restrictions directly but rely on the interpretation of residual effects. Hence, the operationalisation of fee-based and non-contributory extracurricular organisations is in the focus. Especially church communities as indicator for noncontributory organisation limits the analysis insofar as they do not cover all non-contributory, institutionalised leisure activities. Although the operationalisation is not fully satisfying, the analysis reveals new insights into poverty-related withdrawal mechanisms. 
Fewer opportunities to participate result in educational disadvantages. This fact is often neglected in the debate on social mobility and social justice even though unevenly distributed informal learning opportunities can represent social selection instances with regard to education (Düx and Rauschenbach 2010). Therefore, the goal of a supportive society must be to mitigate discrimination processes. Activities organised by church communities can play a useful role because charity and the dignity of the poor are inherent characteristics of the open youth work of churches. Our results suggest that religious organisations offer young individuals a chance to participate in social life relatively independently of their available economic capital. Furthermore, a reimbursement of expenses for clubs and courses by the government may increase participation opportunities for youths from low-income households. An example of a municipal instrument could be material compensation for sports, cultural and recreational experiences. In contrast, it is substantially more difficult to counter psychosocially motivated withdrawal tendencies. In this case, status changes and the duration of material shortages become the focus of the analysis. Longitudinal data offer an opportunity to identify such dynamics at the individual level, whereas PASS is a suitable database for future research.

\section{Executive summary}

This paper analyses poverty-specific withdrawal mechanisms of children and adolescents: it examines the connection between poverty and the social participation of young people. In addition to an integration effect, social participation in, for example, extracurricular organisations provides knowledge and skills, which can be profitably incorporated in other social contexts, such as school and work. However, access to organisations in which informal learning processes occur may be limited as a result of various mechanisms, particularly for needy children and young individuals.

In the public discourse on equal access to education and participation opportunities, informal learning usually plays a minor role. However, the acquisition of extracurricular skills during childhood and adolescence is increasingly important to secure the individual benefits required to compete for coveted jobs and traineeship positions. Poverty research has demonstrated that monetary resources restrict opportunities for participation but that withdrawal also occurs because of shame. Poor children and youth are ashamed of the poverty of their parents and internalise their parents' lack of self-esteem. Thus, they withdraw from previous contacts or avoid them from the beginning. Both mechanisms-financial constraints and social withdrawal because of shame-result in an accumulation of educational disadvantages for children and young individuals affected by poverty.
This article addresses the question of whether financial constraints restrict participation in extracurricular contexts or whether withdrawal is causative. To investigate this question empirically, we divide extracurricular leisure activities into fee-based and non-contributory organisations. If financial constraints are the decisive factor for participation, different participation rates should be found only in fee-based and not in non-contributory organisations. However, if financial constraints only play a minor role with social withdrawal being the main cause, then lower participation should also be observed in non-contributory organisations. We operationalize participation in sport, music or cultural clubs as fee-based activities and leisure activities organised by church communities as non-contributory activities. The access to both types of leisure opportunity is open to all regardless of social or religious background.

Our empirical cross-sectional analysis is based on the panel study "Labour Market and Social Security" (PASS). The population under investigation refers to the third wave of PASS which was conducted in 2008 and 2009. We select all of the respondents who are between 15 and 24 years of age. To represent the economic situation of the young individuals and particularly whether they are affected by poverty, we distinguish three groups: (1) no poverty, (2) relative but not combated poverty and (3) combated poverty. The category "combated poverty" includes all persons and households who receive social welfare benefits. This group includes households that receive basic social benefits for employable beneficiaries in accordance with the German Social Code Book II (e.g., ALG II). The relative but not combated poverty group complements the combated poverty group. The difference is that these households do not receive Unemployment Benefit II. Based on a joint consideration of the EU member states, the poverty line is established at 60 per cent of the median national equivalent income. The net household equivalence income takes different household sizes into account. Based on the employed PASS data, we obtain a median equivalent income of $€ 1,333$ and a poverty line of $€ 800$. Thus, the relative but not combated poverty group consists of those young individuals whose household income is below that level but who do not receive Unemployment Benefit II. If individuals are affected by either combated or relative poverty, we assign them to the remaining group. That is, 73 per cent belong to the not poor group (1), 18 per cent belong to the relatively poor but not combated group (2) and 9 per cent belong to the combated poor group (3).

The results demonstrate a clear link between poverty and lower social participation, especially in fee-based organisations. Thus, financial constraints decrease the opportunities for social participation, which strongly limits informal learning opportunities. However, less participation in non-contributory activities, which reflects the processes of 
social withdrawal, is not clearly evident. In particular, a lesser probability of participation was not detected for needy young individuals who do not receive Unemployment Benefit II. This result suggests that social deprivation most likely occurs only when poverty is long-lasting. However, it is worth mentioning that we do not test social withdrawal and financial restrictions directly but rely on the interpretation of residual effects. Hence, the operationalization of fee-based and non-contributory extracurricular organisations is in the focus. Especially church communities as indicator for noncontributory organisation limits the analysis insofar as they do not cover all non-contributory, institutionalised leisure activities. Although the operationalization is not fully satisfying, the analysis reveals new insights into poverty-related withdrawal mechanisms.

\section{Kurzfassung}

Ziel des Aufsatzes ist es, armutsspezifische Rückzugsmechanismen von Kindern und Jugendlichen zu analysieren. Insbesondere der Zusammenhang zwischen Armut bzw. Armutsgefährdung und sozialer Teilhabe junger Menschen soll betrachtet und aufgezeigt werden. Soziale Teilhabe zum Beispiel in außerschulischen Organisationen vermittelt neben einer integrationsstiftenden Wirkung, Wissen und Kompetenzen, welche auch in anderen sozialen Kontexten, wie Schule und Beruf, gewinnbringend eingebracht werden können. Der Zugang zu Organisationen, in denen Prozesse informellen Lernens stattfinden, kann jedoch aufgrund vielfältiger Mechanismen eingeschränkt sein, insbesondere für von Armut betroffene Kinder und Jugendliche.

Im Zuge der öffentlichen Diskussion um einen gleichberechtigten Zugang zu Bildungs- und Teilhabechancen spielt das informelle Lernen zumeist nur eine untergeordnete Rolle. Jedoch wird der außerschulische Erwerb von spezifischen Fähigkeiten und Fertigkeiten während der Kindheit und Jugend zunehmend bedeutsam, um individuelle Startvorteile im Wettstreit um begehrte Ausbildungs- und Arbeitsplätze zu sichern. Aus der Armutsforschung ist bekannt, dass verringerte Teilhabechancen nicht nur auf monetäre Restriktionen zurückzuführen sind, sondern auch auf einen generellen Rückzug aufgrund von Schamgefühlen. Arme Kinde und Jugendliche schämen sich für die Armut ihrer Eltern und verinnerlichen das mangelnde Selbstwertgefühl ihrer Eltern. In der Folge ziehen sie sich früh aus sozialen Kontakten zurück oder sie bahnen Kontakte erst gar nicht an. Beide Mechanismen - sozialer Rückzug aufgrund von finanziellen Engpässen sowie aufgrund von Schamgefühlen - führen zu einer Akkumulation von bildungsbiografischen Benachteiligungen armutsbetroffener Kinder und Jugendlicher.

Dieser Beitrag geht der Frage nach, ob finanzielle Restriktionen die Teilhabe an außerschulischen Lernkontexten restringieren oder ob vielmehr ein genereller Rückzug ursächlich ist. Um dies empirisch zu testen, untergliedern wir außerschulische Freizeitaktivitäten in kostenpflichtige und beitragsfreie Angebote, operationalisiert über (kostenpflichtige) Sport-, Musik- und Kulturvereine sowie (beitragsfreie) kirchliche Angebote. Wenn finanzielle Restriktionen ausschlaggebend sind, dann sollten unterschiedliche Teilhabequoten nur bei kostenpflichtigen, nicht aber bei beitragsfreien Angeboten anzutreffen sein. Spielen hingegen finanzielle Restriktionen nur eine untergeordnete Rolle und sozialer Rückzug ist ursächlich, dann sollte auch in beitragsfreien Angeboten eine geringere Teilhabe beobachtbar sein.

Als Datengrundlage dient das Panel Arbeitsmarkt und Soziale Sicherung (PASS). Die zugrunde liegende Untersuchungspopulation bezieht sich auf die dritte Welle des PASS, welche zwischen 2008 und 2009 erhoben wurde. Wir berücksichtigen hierbei nur Befragte zwischen 15 und 24 Jahre. Um die ökonomische Situation der Kinder und Jugendlichen und insbesondere deren Armutsbetroffenheit abzubilden, werden diese in drei Gruppen unterteilt: (1) keine Armutsbetroffenheit, (2) relative, aber nicht bekämpfte Armut, (3) bekämpfte Armut. In der Kategorie bekämpfte Armut werden Personen und Haushalte zusammengefasst, die sozialstaatliche Transferleistungen beziehen. In diese Gruppe fallen Haushalte, die Grundsicherungsleistungen für erwerbsfähige Leistungsberechtigte nach dem Zweiten Sozialgesetzbuch (u.a. ALG II) beziehen. Hierunter fällt auch der Anspruch auf die Leistungen des bereits erwähnten Bildungs- und Teilhabepakets. Die Gruppe der relativen Armut steht in Ergänzung zur bekämpften Armut. Als relativ arm werden armutsgefährdete Haushalte angesehen, die jedoch kein ALG II beziehen. Nach gemeinsamer Festlegung der EU-Mitgliedstaaten liegt die Armutsgefährdungsgrenze bei einem Nettoäquivalenzeinkommen von weniger als $60 \%$ des Medians. Das bedarfsgewichtete Nettoäquivalenzeinkommen berücksichtigt zudem verschiedene Haushaltsgrößen. Anhand der verwendeten PASS-Daten ergeben sich ein Median- Äquivalenzeinkommen von 1.333 Euro und eine Armutsgefährdungsgrenze von 800 Euro. Zu der Gruppe der relativ Armen werden demnach die jungen Menschen zugeordnet, deren Haushalt ein Einkommen unter diesem Wert in den PASS-Daten aufzeigt, gleichzeitig jedoch keine Leistungen nach dem SGB II in Anspruch nimmt. Alle anderen Personen werden der ersten Gruppe zugeteilt. Somit werden $73 \%$ der Gruppe ohne Armutsbetroffenheit (1), $18 \%$ der Gruppe der Armen ohne ALG II Bezug (2) und $9 \%$ der Gruppe der ALG II Beziehern (3) zugeordnet.

Fasst man die Ergebnisse zusammen, so wird ein direkter Zusammenhang zwischen Armut und geringerer sozialer Teilhabe offensichtlich; Armutsbetroffenheit schränkt die Teilhabe an kostenpflichtigen Organisationen erheblich ein. Finanzielle Engpässe reduzieren die Möglichkeit sozialer Teilhabe, wodurch die Potentiale informellen Lernens stark 
begrenzt werden. Eine geringere Teilhabe an beitragsfreien Angeboten, welche Prozesse des sozialen Rückzugs widerspiegeln, ist hingegen nicht eindeutig nachzuweisen. So finden sich bei Jugendlichen, deren Haushalte ALG II beziehen, Hinweise für gesellschaftliche Exklusion, wenngleich diese mit Vorbehalt zu interpretieren sind. Für armutsbetroffene Jugendliche ohne ALG II Bezug lassen sich hingegen keine geringeren Teilhabewahrscheinlichkeiten nachweisen. Dieses Ergebnis deutet daraufhin, dass soziale Deprivation wahrscheinlich erst mit verstetigter Armut einhergeht. Einschränkend muss erwähnt werden, dass wir beide Rückzugsmechanismen nur indirekt messen können. Von daher ist es wichtig, die abhängigen Variablen für kostenpflichtige und beitragsfreie Angebote nochmals in den Blick zu nehmen. Insbesondere die Operationalisierung beitragsfreier Angebote mit kirchlichen Freizeitaktivitäten ist nicht völlig zufriedenstellend. Dennoch gewährt die Analyse bei der gegebenen Datenlage neue Einblicke in armutsspezifische Rückzugsmechanismen.

\section{References}

AEJ: Evangelische Jugend: Jugendpolitik ist auf die Sichtweisen junger Menschen angewiesen. Pressemitteilung 4/2010. Arbeitsgemeinschaft der Evangelischen Jugend in Deutschland, Hannover (2010)

Andreß, H.J., Lipsmeier, G., Salentin, K.: Soziale Isolation und mangelnde soziale Unterstuetzung im unteren Einkommensbereich? Vergleichende Analysen mit Umfragedaten. Z. Soziol. 24, 300315 (1995)

Auspurg, K., Hinz, T.: Gruppenvergleiche bei Regressionen mit binaeren abhaengigen Variablen - Probleme und Fehleinschaetzungen am Beispiel von Bildungschancen im Kohortenverlauf. Z. Soziol. 40, 62-73 (2011)

Bauer, T.: Kinder, Zeit und Geld. Eine Analyse der durch Kinder bewirkten finanziellen und zeitlichen Belastungen von Familien und der staatlichen Unterstuetzungsleistungen in der Schweiz Mitte der Neunziger Jahre. Sonderreihe "Familie und Gesellschaft". Büro für arbeits- und sozialpolitische Studien, Bern (1998)

Becker, G.S.: Investment in human capital: a theoretical analysis. J. Polit. Econ. 70, 9-49 (1962)

BMAS: Lebenslagen in Deutschland. Entwurf des 4. Armuts- und Reichtumsbericht der Bundesregierung. Bundesministerium für Arbeit und Soziales, Berlin (2012)

Bourdieu, P.: Ökonomisches Kapital, kulturelles Kapital, soziales Kapital. In: Kreckel, R. (ed.) Zur Theorie der Sozialen Ungleichheit. Soziale Welt, Sonderband 2, pp. 183-198. Schwartz, Göttingen (1983)

Braun, S., Hansen, S., Ritter, S.: Vereine als Katalysatoren sozialer und politischer Kompetenzen? Ergebnisse einer qualitativen Untersuchung. In: Schwalb, L., Walk, H. (eds.) Local Governance - mehr Transparenz und Bürgernähe? pp. 109-130. VS Verlag, Wiesbaden (2007a)

Braun, S., Hansen, S., Ritter, S., Sliep, K., Weiß, C.: Sozialkapital und Buergerkompetenz - soziale und politische Integrationsleistungen von Vereinen. Eine theoretische und empirische Untersuchung. VS Verlag, Wiesbaden (2007b)

Breuer, C.: Sportvereine in Deutschland. Sportentwicklungsbericht 2007/2008. Analyse zur Situation der Sportvereine in Deutschland. Kurzfassung. Bundesinstitut für Sportwissenschaft, Sportverlag Strauß, Köln (2009)
Brinkmann, C.: Die individuellen Folgen langfristiger Arbeitslosigkeit. Ergebnisse einer repraesentativen Laengsschnittuntersuchung. Mitt. Arb.markt- Berufsforsch. 17, 454-473 (1984)

Bundesagentur für Arbeit: Arbeitsmarkt 2011. Amtliche Nachrichten der Bundesagentur für Arbeit (ANBA), Jahrgang 59, Sondernummer 2. Bundesagentur für Arbeit, Nuernberg (2012)

Cast, A.D., Burke, P.: A theory of self-esteem. Soc. Forces 80, 10411068 (2002)

Coser, L.A.: Soziologie der Armut: Georg Simmel zum Gedaechtnis. In: Leibfried, S., Voges, W. (eds.) Armut im modernen Wohlfahrtsstaat. Köln Z. Soziol. Soz. Psychol. (Sonderheft), Vol. 32, pp. 34-47. Westdeutscher Verlag, Opladen (1992)

Deckl, S.: Leben in Europa 2009. Bundesergebnisse für Sozialindikatoren über Einkommen, Armut und Lebensbedingungen. Statistisches Bundesamt, Wiesbaden (2011)

Deutsche Bischofskonferenz: Katholische Kirche in Deutschland. Zahlen und Fakten 2011/12. Arbeitshilfen 257. Sekretariat der Deutschen Bischofskonferenz Bonn (2012)

Diewald, M.: Arbeitsmarktungleichheiten und die Verfuegbarkeit von Sozialkapital. Die Rolle von Gratifikationen und Belastungen. In: Franzen, A., Freitag, M. (eds.) Sozialkapital. Theoretische Grundlagen und empirische Befunde. Köln. Z. Soziol. Soz.psychol. (Sonderheft), Vol. 47, pp. 183-210 (2007)

Dohmen, G.: Das informelle Lernen. Die internationale Erschliessung einer bisher vernachlaessigten Grundform menschlichen Lernens für das lebenslange Lernen aller. Bundesministerium für Bildung und Forschung, Bonn (2001)

DPSG: Der Mitgliedsbeitrag in der DPSG. Eine Information für Vorstaende. Leiterinnen und Leiter. Bundesamt Deutsche Pfadfinderschaft Sankt Georg, Neuss (2011)

Düx, W., Prein, G., Sass, E., Tully, C.J.: Kompetenzerwerb im freiwilligen Engagement. Eine empirische Studie zum informellen Lernen im Jugendalter. VS Verlag, Wiesbaden (2008)

Düx, W., Rauschenbach, T.: Informelles Lernen im Jugendalter. In: Neuber, N. (ed.) Informelles Lernen im Sport: Beiträge zur allgemeinen Bildungsdebatte, pp. 53-77. VS Verlag, Wiesbaden (2010)

EKD: Kirche und Jugend Lebenslagen: Begegnungsfelder Perspektiven. Eine Handreichung des Rates der Evangelischen Kirche in Deutschland. Guetersloher Verlagshaus, Guetersloh (2010)

Engels, D., Thielebein, C.: Zusammenhang von sozialer Schicht und Teilnahme an Kultur-, Bildungs- und Freizeitangeboten für Kinder und Jugendliche. Schlussbericht. Forschungsprojekt: Lebenslagen in Deutschland: Armuts- und Reichtumsberichterstattung der Bundesregierung. Bundesministerium für Arbeit und Soziales, Köln (2010)

Gaiser, W., Rijke, J.d.: Gesellschaftliche und politische Beteiligung. In: Gille, M., Sardei-Biermann, S., Gaiser, W., Rijke, J.d. (eds.) Jugendliche und junge Erwachsene in Deutschland, pp. 213-275. VS Verlag, Wiesbaden (2006)

Gensicke, T., Picot, S., Geiss, S.: Freiwilliges Engagement in Deutschland 1999-2004. Ergebnisse der repraesentativen Trenderhebung zu Ehrenamt, Freiwilligenarbeit und bürgerschaftlichem Engagement. VS Verlag, Wiesbaden (2006)

Gillen, G., Möller, M.: Anschluss verpasst: Armut in Deutschland. Dietz, Bonn (1992)

Grunert, C.: Bildung und Lernen - ein Thema der Kindheits- und Jugendforschung? In: Rauschenbach, T., Düx, W., Sass, E. (eds.) Informelles Lernen im Jugendalter. Vernachlaessigte Dimensionen der Bildungsdebatte, pp. 15-35. Juventa, Weinheim/Muenchen (2006)

Hauser, R.: Zur Messung individueller Wohlfahrt und Ihrer Verteilung. In: Bundesamt, S. (ed.) Wohlfahrtsmessung. Aufgabe der Statistik im gesellschaftlichen Wandel, pp. 13-38. Metzler-Pöschel, Stuttgart (1996)

Höß, M.: Konzept. Offene Jugendarbeit. Kirchliche Jugendarbeit Diözese Würzburg, Würzburg (2004) 
Isengard, B.: Freizeitverhalten als Ausdruck sozialer Ungleichheiten oder Ergebnis individualisierter Lebensführung? Zur Bedeutung von Einkommen und Bildung im Zeitverlauf. Köln. Z. Soziol. Soz.psychol. 57, 254-277 (2005)

Kern, S.: Führt Armut zu sozialer Isolation? Eine empirische Analyse mit Daten des Sozio-Ökonomischen Panels. Universitätsbibliothek Trier (2004)

KJG: Informationen für Eltern und Kinder. Katholische Junge Gemeinde Diözesanverband, Würzburg (2011)

Leibfried, S., Leisering, L., Buhr, P., Ludwig, M., Maedje, E., Olk, T., Voges, W., Zwick, M.: Zeit der Armut. Lebensläufe im Sozialstaat. Suhrkamp, Frankfurt am Main (1995)

Lipski, J.: Für das Leben lernen - aber wo? Anmerkungen zum Verhaeltnis von informellem und schulischem Lernen. In: Deutsches, J. (ed.) Informelles Lernen in der Freizeit. Erste Ergebnisse des Projekts "Lebenswelten als Lernwelten", pp. 43-51. DJI, München (2000)

Otto, H.-U., Kutscher, N.: Informelle Bildung online. Perspektiven für Bildung, Jugendarbeit und Medienpaedagogik. Juventa, Weinheim/München (2004)

Puls, W.: Soziale Isolation und Einsamkeit. Ansätze zu einer empirisch-nomologischen Theorie. Deutscher Universitätsverlag, Wiesbaden (1989)

Rauschenbach, T., Leu, H.R., Lingenauber, S., Mack, W., Schilling, M., Schneider, K., Züchner, I.: Non-formale und informelle Bildung im Kindes- und Jugendalter. Konzeptionelle Grundlagen für einen nationalen Bildungsbericht. BMBF, Berlin (2004)

Sauer, F.-J., Kossens, M.: SGB II Grundsicherung für Arbeitsuchende: Kommentar zum SGB II. Haufe, Freiburg (2011)

Simmel, G.: Soziologie. Untersuchungen über die Formen der Vergesellschaftung. Duncker \& Humblot, Leipzig (1908)

Smith, A.: The Theory of Moral Sentiments. Library of Economics and Liberty. http://www.econlib.org/library/Smith/smMS.html (1790). Downloaded on September, 22. 2012
Stecher, L.: Informelles Lernen bei Kindern und Jugendlichen und die Reproduktion sozialer Ungleichheit. Z. Erzieh.wiss. 8, 374-393 (2005)

Thole, W., Höblich, D.: "Freizeit" und "Kultur" als Bildungsorte Kompetenzerwerb über non-formale und informelle Praxen von Kindern und Jugendlichen. In: Rohlfs, C., Harring, M., Palentien, C. (eds.) Kompetenz-Bildung. Soziale, emotionale und kommunikative Kompetenzen von Kindern und Jugendlichen, pp. 69-93. VS Verlag, Wiesbaden (2008)

Trappmann, M., Gundert, S., Wenzig, C., Gebhardt, D.: PASS: a household panel survey for research on unemployment and poverty. Schmollers Jahrb. Wirtsch.- Soz.wiss. 130, 609-622 (2010)

Traunmüller, R.: Religion und Sozialintegration. Eine empirische Analyse der religiösen Grundlagen sozialen Kapitals. Berl. J. Soziol. 3, 435-468 (2009)

Tully, C., Wahler, P.: Erlebnislinien zu ausserschulischen Lernen. In: Wahler, P., Tully, C., Preiß, C. (eds.) Jugendliche in neuen Lernwelten, pp. 189-212. VS Verlag, Wiesbaden (2004)

Wolf, C., Best, H.: Logistische Regression. In: Wolf, C., Best, H. (eds.) Handbuch der sozialwissenschaftlichen Datenanalyse, pp. 827854. VS Verlag, Wiesbaden (2010)

Zinnecker, J.: Projekt Bildungsmoratorium. Zielsetzung und Untersuchungsdesign. Projektbroschuere Nr. 5. Universitaetsdruck, Siegen (1994)

Dr. Andreas Damelang is a lecturer for empirical social research at the University Erlangen-Nuremberg. He was a scholarship holder in IAB's Graduate Programme (GradAB) from 2008 to 2010. Georgi Kloss graduated in Socio-Economics at the University of ErlangenNuremberg in 2012, specializing in Behavioural Sciences. Currently, he pursues a master's degree in Marketing Research and works as a freelancer for the Research Institute for Vocational Education and Training (f-bb). 